UDC 378.026

\title{
SYSTEM APPROACH IMPLEMENTATION FOR THE PURPOSES OF HIGHER EDUCATIONAL ESTABLISHMENT STUDENTS' KEY COMPETENCES FORMATION
}

\author{
Udovichenko H.M., Ostapenko S.A. \\ Donetsk National University of Economics and Trade \\ named after Mykhaylo Tuhan-Baranovsky
}

\section{DOI: https://doi.org/10.32839/2304-5809/2018-12-64-106}

The purpose of this article is to describe the feasibility of using a system approach to the formation of the higher educational establishment students' key competences formation, and this phenomenon definition propriety by the pedagogical system. In the learning policy of higher education, formation of various didactic and pedagogical phenomena is in process. Analyzing the problems of training and education, determining the process of higher educational establishment students' key competences formation by the pedagogical system, one can conclude that they need a system approach in the course of their development. The situation prevailing in the professional training of the specialist encourages educational institutions to look for ways to improve the educational process. It is known that from the standpoint of a systematic approach, the learning process is regarded as a system that is subject to planning and developing a clear hierarchy of goals, knowledge and skills that comply with the overall ultimate goal of the system all components, and is also in constant development. Changing or replacing one parameter or component significantly affects all others. A system approach emerged as a response to the long-standing domination of analytical research method, which is inadequate in cases where the object being studied contributes the need to correlate its parts with one another or to correlate a part and the whole, to establish the relationship between, at first glance, incomparable facts accumulated within even one research work, as well as when it is necessary to search for analogies and similarities in phenomena of different origins.

Keywords: theory of systems, systematic approach, educational systems, pedagogical systems, key competences, higher educational establishment.

Tntroduction. In the learning policy of higher Leducation, formation of various didactic and pedagogical phenomena is in process. Analyzing the problems of training and education, determining the process of higher educational establishment students' key competences formation by the pedagogical system, one can conclude that they need a system approach in the course of their development. In the educational field, the theory of systems is implemented at all levels where such concepts as "education system", "system of professional education", "pedagogical system", etc. are known. Social institutions, the main activities of which are educational activities and the most prominent representative of which are higher educational institutions, their departments and units, general training of experts, training of specialists in the field, training within the discipline or topic of instruction, subject and object, goals, content, rules, regularities, principles, methods, forms, means of training and education, etc. are considered as a system [7, p. 7].

Analysis of scientific literature. The situation prevailing in the professional training of the specialist encourages educational institutions to look for ways to improve the educational process. This problem has been defined by the analysis of trends in the development of education over the past decades, as it is shown in the works of N. Kolesnyk, G. Kyrylova, Yu. Shabanova and others.

Formulation of the problem. The purpose of this article is to describe the feasibility of using a system approach to the formation of the higher educational establishment students' key competences formation, and this phenomenon definition propriety by the pedagogical system.

Body of Paper. The obvious spread of system researches according to modern researchers in the field of system research methodology (I. Blauberg, V. Sadovsky, E. Yudin) have three courses: firstly, most of the social sciences and humanities are essentially transforming subjects of research. As such, a variety of interconnected elements are now emerging, which can be regarded as integral entities. Secondly, the widespread introduction of automation and computerization, the growth of technical progress, led to the fact that the main object of modern design and construction appeared to be management systems, which in their structure and process of creation act as typical examples of system objects. Finally, the awareness of the fact that a broad introduction of systematic studies to modern science and technology has redoubled attention to the problems of the general theory of systems.

The Ukrainian pedagogical dictionary gives the following definition: "The system is a set of elements that are in interaction, this is a variety of objects together with the relations between objects and their attributes" [3].

A system approach emerged as a response to the long-standing domination of analytical research method, which is inadequate in cases where the object being studied contributes the need to correlate its parts with one another or to correlate a part and the whole, to establish the relationship between, at first glance, incomparable facts accumulated within even one research work, as well as when it is necessary to search for analogies and similarities in phenomena of different origins.

The need for such a method of research that would allow the possibility of explaining the relationship between the part and the whole, to combine the set of already existing scientific facts and those being under research into a general system of concepts, to establish general patterns for 
different quality classes of phenomena led to the emergence of a new scientific movement, which is called a "system approach".

The general theory of systems has positively influenced the development of the conceptual apparatus, the disclosure of systems and their common properties description formal-logical aspects. However, the general theory of systems has certain significant disadvantages. They become obvious in the formal signs and differences between systems absolutization, in ignoring different system objects quality specifics, in underestimating the historical and dynamic aspects of system development, in their structural and functional elements excessive accentuation, in the consideration of system elements as long-haul and beyond their genetic connections, in calquing the principles of cybernetics on biological and social phenomena, in their mechanical transfer and the application of previously established mathematical models to existing reality objects of different quality.

To the present date, there is not yet a single assessment of the system approach scientific value scale by the Ukrainian didacticians. At least a few trends have been identified. One of them is connected with the consideration of the system approach as a universal principle and its introduction to the world outlook level. The system approach in the education, according to the study of its problems by I. Malafiik, is specified in the system prism method, which involves: 1) the system goal and its functions definition; 2) system-creating factor establishing; 3) system elements separation; 4) determining the level of the hierarchy of the "process" system, that is, the coordination and subordination links; 5) the "process" system elementary structure development and the system elements bringing in the interaction; 6 ) the emergence of the system (emergent) property and its relational effect on the elements of the system. Since all the functional-morphological components are linked together into a single whole and form a functional-morphological structure, it is, in the opinion of the researcher, being mastered by the student and being in a state of psychological readiness, will be the very scheme that the student can use to gain new knowledge [6].

In accordance with another trend, the system approach is treated as the cross-science principle, or the methodology of cognition. The system approach dominates during the methodological substantiation of the higher educational institutions students' educational activity organization. In philosophical and psychological-pedagogical literature, the system approach is considered mainly as a way of studying complex objects, their components, which are in constant dynamic interconnections and interdependence. Systematicity or integrity, above all, assumes that the integrated dynamic, interconnected set of elements of a complex object has characteristics that are radically different from the simple sum or set of characteristics that are inherent to individual components or elements of the entire system [5].

It is the systematic approach to the pedagogical processes study (V. Afanasyev, B. Bespalko, T. Ilyina, N. Kuzmina, V. Lazarev, E. Pavliutenkov, etc.) that provides an opportunity to determine the provisions that are important for students' key competences formation analysis and mechanisms disclosure. The conceptual terminology apparatus and the essence of the system approach are thoroughly considered by many scholars who point out that the key is the principle of systematicity, which consists in the fact that the object must be considered, firstly, as a whole, that is, to have a certain level of integrity, the feature of which is the fact that the system, through the interaction of components, receives an integrated result; and secondly, as a set of interconnected elements, connections between subsystems and components; and thirdly, as an element that has connection with other systems of the environment, and is an element of a higher level system. System approach as a methodological basis for the development and perception of the surrounding reality involves consideration of the object, phenomenon, and process as a holistic dynamic complex system.

It is known that from the standpoint of a systematic approach, the learning process is regarded as a system that is subject to planning and developing a clear hierarchy of goals, knowledge and skills that comply with the overall ultimate goal of the system all components, and is also in constant development. Changing or replacing one parameter or component significantly affects all others. The pedagogical system of student's any competence formation is a subsystem of a higher hierarchical level which is the educational process in the higher school as a whole, and the students' professional competence formation in it. These pedagogical systems, in their turn, contain a plurality of interrelated elements that also possess systemic features. Taking into account the foregoing, it can be argued that the students' professional competence formation is ensured on the condition of interaction and taking into account all the various regularities and relationships that arise between all structural and functional constructs.

Representatives of the third point of view consider only research technology in the system approach. In applied research, the systematic approach is used in two complementary forms - analytical and synthetic. In the first case, it is assumed that the whole is disintegrated into subsystem and the elements, and in the second one it is envisaged to integrate them. An analytical form is appropriate at the stage of designing and developing various systems and organizations, a synthetic form when developing abstract models and describing system objects.

Despite the general recognition, which a systematic approach received in various areas of knowledge, it still does not have well-defined general principles. This makes itself evident primarily in polysemanticity of the "system" notion definitions, the variety of system objects classifications. All the various approaches to defining the "system" concept may be allocated into two groups. In one of these groups, integrity is determined as an essential feature of any system, while in the other - the system is considered as the plurality of elements along with their relations. In pedagogy, the second group of definitions is represented by the point of view of N. Kuzmina, who believes that the educational system is "a set of interconnected structural and functional components, subordinate to the 
goals of upbringing, education and training of the younger generation and adults" [4].

The multiplicity and diversity of the existing objective world is the basis for distinguishing in a logical construct a large number of systems, the qualitative specificity and differences of which complicate the general definition formulation. At the same time, many researchers point to the possibility of distinguishing an invariant feature in the already existing "system"concept definitions. As such invariant content in this concept the idea of interaction of a plurality of parts, elements and their integration into a whole is considered. V. Afanasyev offers a number of features by which systems can be described as integral entities:

- the presence of integrative qualities (systematicity), those qualities that are not inherent in any of the individual elements that form the system;

- the presence of complex elements, components, parts forming the system;

- the presence of a structure, that is, the corresponding relationships and relations between parts and elements;

- availability of functional characteristics of the system as a whole and the individual components of it;

- the existence of communicative features of the system, which manifest themselves in two forms: in the form of interaction with the environment and the form of interaction of this system with sub- and supersystems, that is, systems of lower and higher level in relation to which it acts as a part (subsystem) or as a whole;

- historicity, continuity or connection of the past, present and future in the system and its components [2].

In addition to common features for all systems, the following features of the system, such as purpose availability and manageability, are distinguished as specific properties of biological and social (didactic) systems. Most of these features are the basis of the existing classifications of system objects.

There are many ways to distinguish systems depending on the given criterion, on the basis of which the reality is considered. Thus, according to on substantive foundation and origin, systems are divided into real systems - objects of inanimate, animated and social nature, and conceptual or ideal systems - concepts, theories, models, and so on, artificial systems, that is, systems created by man, as well as mixed systems, which can combine elements of natural, artificial and social nature, such as biotechnical, socio-technical, and others.

By the level of complexity, i.e. the number of elements and connections between them, systems are divided into simple and complex, small and large, ultra-complex and paradoxical (over- or supersystems).

As a result of varying general characteristics change degrees researchers distinguish static and dynamic systems. In order to emphasize the degree of system stability in certain specified constraints, fixed and mobile systems are distinguished.

Depending on the nature of the connections with the environment, as well as on the peculiarities of substance, energy and information exchange between the environment and systems, the latter are divided into closed and open.
From the standpoint of determination, the system is classified into probabilistic and deterministic. The presence and absence of goals provides grounds for delineating systems as purposeful and purposeless. In the context of purpose-oriented systems, they are classified into adaptive, or self-organizing, self-replicating, and developing.

On a manageable basis, systems can be divided into unmanaged, managed and self-guided.

With the help of these common features and attributes, we will describe the educational and pedagogical systems that relate to social systems:

- on the basis of the elements property - artificial;

- goals presence - purposeful;

- as for content - social; for the internal organization - centralized;

- in a hierarchical structure - multilevel;

- as for reflection in the minds of people physical (real);

- on the basis of manageability - self-guided.

These characteristics of systems are provided by implementing the following relationships between their elements:

- according to the forms of matter motion - social;

- direction of action - direct and inverse;

- according to the content - information transfer;

- according to the forms of determinism - correlative;

- by type of processes occurring in systems of management, development and functioning.

The peculiarity of educational and pedagogical systems is that they can and have to be discovered both by static (structural) characteristics and by dynamic (procedural) [7, p. 8].

Like other social systems, educational systems are open because there is a constant exchange of people and information between them and the outside world. For example, the contingent of students and academics of any higher educational institution is constantly partially or completely updated at the expense of human resources of the external environment. In its turn, external, in relation to this educational system, environment takes from it the necessary for the functioning of other social organizations people with a certain level of general or special training.

A functional structure, whose activities are subordinated to a certain purpose, is called the system. Specialists included in a common type of activity also form the system in which this activity is carried out. Consequently, educational institutions and specialists included in special educational activities form a pedagogical system. The whole set of educational and cultural-educational institutions is a system of public education, which contains large pedagogical systems - the system of higher education, the system of secondary specialized education, the system of general secondary education. These great pedagogical systems are outlined by the Law of Ukraine "On Education" (Article 43). The structure of the pedagogical system of higher education includes a number of medium pedagogical systems (these are separate universities) and small pedagogical systems - individual faculties, courses, groups. Thus, the object of pedagogy studying is the system of public education and pedagogical processes. The object of higher education pedagogy is the system of higher education and pedagogical processes in it. 
Pedagogical systems differ in their pedagogical purpose, the content of learning, the contingent of students, the qualifications of academics, forms and ways of managing students' activities processes, the results. However, all systems realize a single goal, which is determined by the state, society.

In the context of purposeful and dynamic systems, educational systems should be referred to the developing ones. They are such due to the dependence of their improvement and development on community, social and scientific and technological progress, along with the structural, functional and historical aspects of educational systems.

Educational systems do not function and develop spontaneously. Changes have subordinate character through management. The initiation of structural and functional components, their integration and interaction with the surrounding environment can be maintained by their own bodies and mechanisms of control. In this sense, educational systems are self-governing.

Thus, educational systems are real (by origin), social (on a substantial basis), complex (in terms of complexity), open (by the nature of interaction with the environment), dynamic (on the basis of variability), probable (by the method of determination), purposeful (in the presence of goals), self-directed (on the basis of manageability).

P. Anokhin emphasized that in order to form a system, the principle factor is not the simple interaction of any set of elements but their interconnection in order to obtain an integral, general effect, result, goal, through which, and by which the plurality of elements involved are arranged into the system [1].

As previously mentioned, the same system object can be considered from different sides, it involves a plurality of grounds, principles and criteria by which it can be divided into elements. The choice of a given criterion is determined by the tasks, objectives of the study, a particular approach or point of view. When the systems are selected, both the system-forming criterion and the conditions for the system's formation must be specified at the same time. The absence of a given criterion or system-forming feature, the factor, can lead to the replacement of one system by another, which consists of the same elements, but is considered from a different point of view. In order to prevent the possibility of such a substitution and mixing of systems, the choice of a single criterion should be considered as the main point of the system approach.

All social systems are functional in nature, because they are aimed at certain goals. Educational and pedagogical systems are also purposeful. All structural transformations in the educational and training environment, composition, degree of various elements involvement in its activities are determined before everything else by that dominator in which these elements or their combination contribute to obtaining a given result. Therefore, the functional approach should be dominant in determining the leading factor or criterion, which forms any social system, including educational one. Such a general criterion for distinguishing the structural elements of the system, which predetermines their mutual proximity and integration, as well as providing the communicative properties of the system and its hierarchical structure, is the education quality management.

Conclusions. The system approach, having received general scientific recognition and public dissemination, is developed in various fields, directions and aspects: theoretical and methodical, formal logic and mathematical, in structural and functional, in historical-genetic and informational, and others. Prospects for the further development of the system approach are associated with its large and diverse application to various phenomena of reality, on the basis of an applied research broad outgrowth.

\title{
References:
}

1. Anokhin, P. Nodal questions of the theory of a functional system, Moscow: Science, 1980 (in Russian).

2. Afanasyev, V. System and society. Moscow: Science, 1980 (in Russian).

3. Goncharenko, S. The Ukrainian Teacher's Dictionary. Kyiv: Lybid, 1997 (in Ukrainian).

4. Kuzmina, N. The subject of acmeology. St.-Petersburg: Politechnica, 2002 (in Russian).

5. Malykchin, O. Organization of independent educational activity of students of higher pedagogical educational institutions: theoretical and methodological aspect: monograph. Kryvyi Rih: Publishing House, 2009 (in Ukrainian).

6. Malafiik, I. System Approach in the Theory and Practice of Education. Rivne: RSHU, 2004 (in Ukrainian).

7. Kochubei, K., Ivashchenko, V. (Eds.) (2014). System approach in high school: manual for graduate students. Uman: PE Zhovtyi, O. Issue "Pedagogy of the Higher School", 2014 (in Ukrainian).

Удовіченко Г.М., Остапенко С.А.

Донецький національний університет економіки і торгівлі імені Михайла Туган-Барановського

\section{ВИКОРИСТАННЯ СИСТЕМНОГО ПІДХОДУ У ПРОЦЕСІ ФОРМУВАННЯ КЛЮЧОВИХ КОМПЕТЕНТНОСТЕЙ СТУДЕНТІВ ЗАКЛАДІВ ВИЩОЇ ОСВІТИ}

\author{
Анотація \\ В статті розглянуто та проаналізовано положення теорії систем, методології системних досліджень, \\ реалізації системного підходу у сучасній дидактиці та контексті формування ключових компетентнос- \\ тей студентів закладів вищої освіти. За допомогою загальних властивостей та ознак описано освітні \\ та педагогічні системи, які відносяться до соціальних систем. \\ Ключові слова: теорія систем, системний підхід, освітні системи, педагогічні системи, ключові компе- \\ тентності студентів закладів вищої освіти.
}


Удовиченко А.М., Остапенко С.А.

Донецкий национальный университет экономики и торговли имени Михаила Туган-Барановского

\title{
ИСПОЛЬЗОВАНИЕ СИСТЕМНОГО ПОДХОДА В ПРОЦЕССЕ ФОРМИРОВАНИЯ КЛЮЧЕВЫХ КОМПЕТЕНТНОСТЕЙ СТУДЕНТОВ ВЫСІІХ УЧЕБНЫХ ЗАВЕДЕНИ
}

\begin{abstract}
Аннотация
В статье рассмотрены и проанализированы положения теории систем, методологии системных исследований, реализации системного подхода в современной дидактике и контексте формирования ключевых компетентностей студентов высших учебных заведений. С помощь общих свойств и признаков описаны образовательные и педагогические системы, которые относятся к социальным системам.

Ключевые слова: теория систем, системный подход, образовательные системы, педагогические системы, ключевые компетентности студентов высших учебных заведений.
\end{abstract}

